\title{
Utilization and Cultivation of Suweg (Amorphophallus paeoniifolius (Dennst.) Nicolson in Areas around Ciremai Mount, Cimanuk Watershed Region
}

\author{
$A Z$ Mutaqin $^{1,3}, D$ Kurniadie $^{1}, J$ Iskandar $^{1,2,3}, M$ Nurzaman $^{3}$, and $T$ Husodo ${ }^{2,3}$ \\ ${ }^{1}$ Program of Environmental Science, Postgraduate School, Universitas Padjadjaran, Indonesia \\ ${ }^{2}$ Center for Environment and Sustainability Science, Universitas Padjadjaran, Indonesia \\ ${ }^{3}$ Departement of Biology, Faculty of Mathematics and Natural Sciences, Universitas Padjadjaran, Indonesia
}

\begin{abstract}
Amorphophallus paeoniifolius (Dennst.) Nicolson which in the local language is popularly known as suweg is a plant that grows widely in Indonesia, including in rural areas around Ciremai Mountain, whose landscape is in the Cimanuk Watershed area. This study aims to examine the knowledge of the population related to the utilization and cultivation of suweg in the Ciremai Mountain area, namely in the Cipulus, Cilancang, Jagasari, and Sindangpanji Village which are administratively included in Cikijing Sub District, Majalengka Regency, West Java Province. This study uses a qualitative method. The data was collected through deep interviews purposively with people who have competence as informants, including owners of the land where the suweg grows, farmers, and public figures. Data analysis was done by crosschecking, summarizing, and synthesizing descriptively narrated. As a result of the research, residents in the four villages informed that the suweg was already at least around 1950, but its exact origin is not known. Generally, suweg is used as jaburan, a type of additional food. Especially in Sindangpanji Village, suweg is also used as fish feed. People in the four villages do not cultivate suweg intensively. Suweg is also not a commodity, but only subsistence.
\end{abstract}

\section{Introduction}

Indonesia has abundant natural resources, both living and non-living. Among the biological natural resources that are widely owned by Indonesia are plants. There are various plant species that grow in Indonesia, whether cultivated, not yet cultivated, or not cultivated. There are 20,000 species of plant species in Indonesia, $40 \%$ of which are endemic. Currently, 240 rare plants are recorded, of which many are cultivated [1]. Rugayah et al. (2017) mentions that there are 50 rare plant species in Indonesia.

Plants are widely used by humans to fulfill their various needs. The needs in question include the need for food, ornamentals, building materials, medicines, animal feed, agricultural tools, and fuel [3]. More generally, Zhang \& Zhou (2019) state that biodiversity, including plants, plays a key role in human welfare by providing agricultural, economic, and health benefits.

The use of plants by humans has been going on for a long time. Humans and plants have a complex relationship that stretches throughout history [5]. Plants are one of the two major groups of living organisms that are an essential entity to the function of the biosphere. They are an essential part of our daily lives providing food, clean air, and important ecosystem functions [6]. Meanwhile, Bennet (2010) states that plants have value as a source of food, energy, medicine, and are related to ritualism/ symbolism. In addition, regarding the importance of plants as producers, Yao et al. (2015) states that plants have the potential to rapidly produce recombinant proteins on a large scale at a relatively low cost compared to other production systems.

Human groups in the world, have a method or knowledge in utilizing natural resources, including plants, which exist in the surrounding environment. Vasconcellos and Sobrinho (2014) state that knowledge as a component of power that is transferred from one social context to another within a system of values and beliefs. Knowledge, as a component of power, is an accumulation of social norms, rituals and practices that are culturally, socially and politically produced as a powerful normative construct. Local knowledge is very unique and residents get their knowledge from experiences of various local practices in interacting with the local environment $[10,11]$. In the same thing, Carvalho \& Moreira (2011) inform that local knowledge is often practical, based on empirical observations and long experience, and is transmitted through oral traditions, but is also a dynamic process capable of integrating various sources of knowledge. Local knowledge that is unique to a given culture or society and contrasts with the western scientific knowledge [13, $11]$.

The knowledge of the population about the use of plants in general may have similarities and differences between one region and another. Maroyi \& Cheikhyoussef (2015) informs that in several countries, there are several things that are the same and or different related to the use of plants by the population which involves several aspects such as the plant species used, the plant organs being processed, and the purpose for which they are used.

The species of plants used by the population are very diverse. One group of plants that are often used by people in various parts of the world are tubers. Suwardi et al. (2018) concluded that several types of tuber plants have good nutritional content and are suitable as alternative food sources. Chandrasekara and Kumar (2016) inform that some tuberous plants that are 
commonly consumed are Solanum tuberosum (Solanaceae), Solenostemon rotundifolius (Lamiaceae), Canna edulis Cannaceae, Maranta arundinacea L. Marantaceae, Dioscorea alata Dioscoreaceae, Ipomoea batatas Convolvulaceae, Manihot esculenta Euphorbiaceae, Xanthosoma sagittifolium (Araceae), and Amorphophallus paeoniifolius (Araceae). Specifically for the Araceae family, Vaneker \& Slaats (2012) stated that the plants are of economic importance and an expression of social and cultural values for around 400 to 500 million people worldwide.

Amorphophallus paeoniifolius is a species of plant from the Araceae family that is widely used by residents. Ramanathan et al. (2014) revealed that this plant in Kollihills, Namakkal District, Tamilnadu is used to treat bronchitis, asthma, and dysentery. Yabesh et al. (2014) also stated that this species of plant is used as a medicine for coughs and liver diseases in Kerala, India. Meanwhile, Mandal et al. (2016) inform that this plant is an edible plant that is widely used in several developing countries. In Indonesia, Mutaqin et al. (2020) states that this species of plant is used by residents, including for supplementary food, fish feed, and traditional ceremonies.

Amorphophallus paeoniifolius is widely distributed in several regions of the world. Tan \& Zaharah (2015) ${ }^{[22]}$ informed that this plant species originated from South and Southeast Asia. In Indonesia, this plant is spread in many regions (Yuzammi et al., 2017) ${ }^{[23]}$. Specifically, Mutaqin et al. (2020) ${ }^{[24]}$ states that this Amorphophallus grows in several land uses such as home gardens, gardens, rice field edges, and pond edges.

Based on the description above, Amorphopallus paeoniifolius (Dennst.) Nicolson or popular with the name local suweg, is widely spread in several parts of Indonesia. Residents use this plant to meet their daily needs. Therefore, it is necessary to have studies to enrich information about suweg. This research is one of the studies that aims to enrich information about the utilization and cultivation of suweg in several areas around Ciremai Mount, including the Cimanuk Watershed Region.

\section{Material and Methods}

This research was conducted in March-August 2020 in several villages around Ciremai Mount which geographically includes the Cimanuk Watershed Region and administratively includes Cikijing sub District, Majalengka Regency, West Java Province, Indonesia (Figure 1). The villages used as research locations were Cipulus Village, Cilancang Village, Jagasari Village, and Sindangpanji Village. In particular, the study areas are divided into three categories. The first category is villages that are close to Ciremai Mount, namely Cipulus and Cilancang Village. The second category of territory is a village some distance from the Ciremai Mount, namely Jagasari Village. Meanwhile, the third category is a village far from Ciremai Mount, namely Sindangpanji Village. Based on information from Statistics of Majalengka Regency (2018), Cipulus Village has an area of 3.45 hectares with an altitude of
890 meters above sea level. The village has a distance of 7 and $40 \mathrm{~km}$ to the capitals of sub district and regency, respectively. Cilancang Village has an area of 1.99 hectares with an altitude of 870 meters above sea level. The village has distances to the capitals of sub district and regency, respectively 7.20 and $40 \mathrm{~km}$. Jagasari Village has an area of 5.70 hectares with an altitude condition of 652 meters above sea level. The village has a distance of 3 and $39 \mathrm{~km}$ to the capitals of sub district and regency, respectively. Sindangpanji Village has an area of 3.50 hectares with an altitude of 629 meters above sea level. The village has 2.5 and $35.5 \mathrm{~km}$ distance to the capitals of sub district and regency, respectively.

This research is ethnobotany research. This research uses qualitative methods [26]. Data collection was carried out through observation and interviews. Observations were made to determine the presence of the suweg in the study area in the sense of validating that the suweg was present or growing in the study area. Apart from that, participatory observation was also carried out in certain matters to validate or strengthen information from the population. The interviews conducted are semi-structured or deep interviews. Interviews were conducted to obtain information on the knowledge of the population, especially regarding the utilization and cultivation of suweg. Interviews were conducted with residents who were considered to have competency knowledge about the suweg through the snow ball technique by taking into account the diversity of informants who were selected purposively. Residents who become informants include local government officials, community leaders, owners of the land where suweg grows, and several residents who work as farmers.

Data analysis was done by cross-checking, summarizing, and synthesizing to then be narrated descriptively. Data analysis was carried out through an ethical and ethical approach $[27,28,11]$.

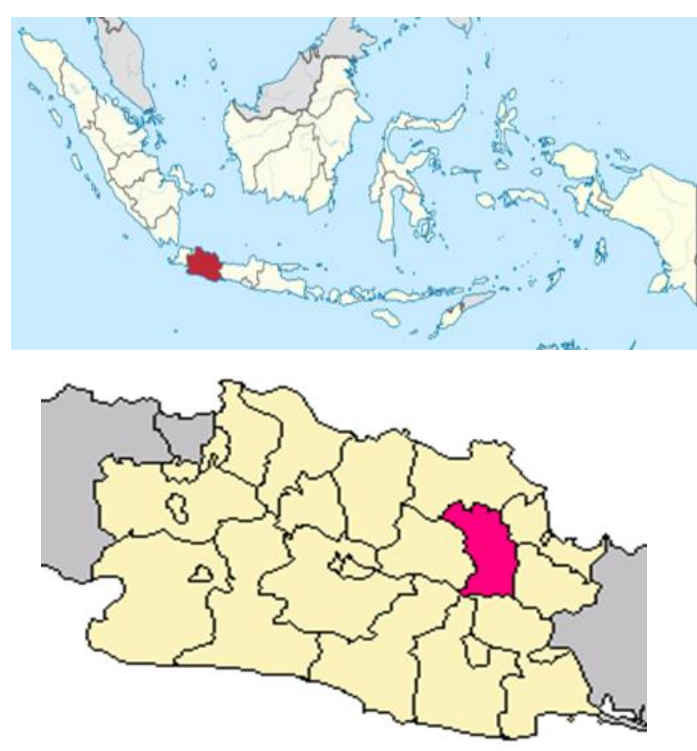

(1A) 


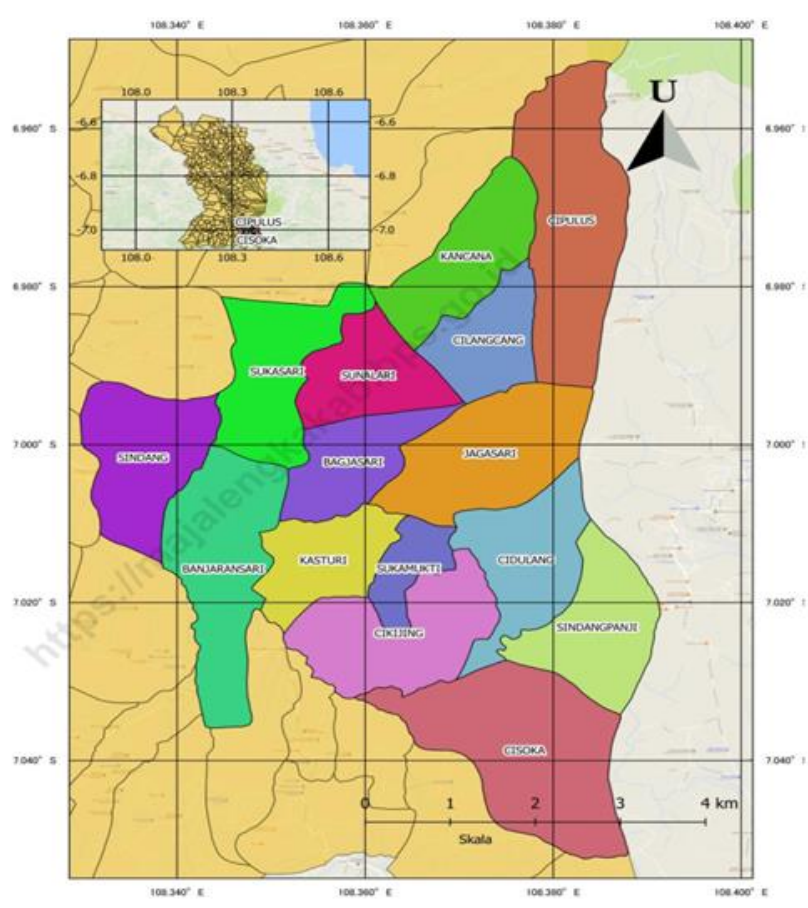

(1B)

Source:

A.https://id.wikipedia.org/wiki/Daftar_kecamatan_dan kelurahan_di_Jawa_Barat, 2020 [29]

B. Statistic of Majalengka Regency, 2018 $8^{[25]}$

Figure 1. Location of research in areas around Ciremai Mount, the Sub-District of Cikijing, the District of Majalengka, West Java, Indonesia

\section{Result}

\subsection{The History of Growing and Utilization of Suweg}

In general, the people around Mount Ciremai, namely in Cipulus Village, Cilancang Village, Jagasari Village, and Sindangpanji Village, Cikijing sub District, Majalengka District, inform that suweg has existed or grown in the surrounding environment for a long time. Several informants who are classified as older informed that around the 1950s, when they were a child, they saw or knew that suweg grew up in the area. However, people do not know for sure the initial time that the suweg grew in their area, including the origin or source of its seeds. Furthermore, the community informed that the suweg that grew or were found around the lands where they lived now (including on land owned by several informants), the initial time of their existence varied (some were only 1 year, 5 years, or more). Sources of suweg seeds come from neighbors in their neighborhood, some from other villages or districts. Suweg seeds are not commercialized or traded.

The utilization of suweg by the community has been going on for a long time. Utilization knowledge is the result of the transfer of knowledge from parents or ancestors. The current condition, the suweg is rather rarely used along with the shrinking of its population as a result of not being too important or attractive to plant suweg as it is for other species of cultivated plants. The scarcity of using suweg is also related to the many choices of other types of food, whether related to more attractive packaging, good taste, ease of processing, instant consumption, or other factors. Especially among the young age group, suweg is not or less popular, both in its use and even in its name or visual form. This may be due to the fact that parents do not introduce suweg to their children or vice versa, the young age group is less concerned and interested in the potential of local resources in their neighborhood, including suweg. The public informed that a general phenomenon that is happening now, many young age groups prefer or are affected by modern things that affect their behavior or lifestyle, including in terms of food.

\subsection{Utilization of Suweg}

The communities around Mount Ciremai, namely the people in Cipulus Village, Cilancang Village, Jagasari Village, and Sindangpanji Village, inform that suweg is used for several of their life needs which can be seen more clearly in Table 1 below:

Table 1 Community knowledge in The around Ciremai Mount about the utilization of suweg

\begin{tabular}{|l|l|l|l|l|}
\hline \multirow{2}{*}{$\begin{array}{l}\text { Utilization } \\
\text { Description }\end{array}$} & \multicolumn{4}{|c|}{ Village } \\
\cline { 2 - 5 } & Cipulus & Cilancang & Jagasari & Sindangpanji \\
\hline 1. Type & Jaburan & Jaburan & Jaburan & $\begin{array}{l}\text { Jaburan } \\
\text { fish feed }\end{array}$ \\
\hline 2. Method & $\begin{array}{l}\text { Di-seupan } \\
\text { (steamed); } \\
\text { fried }\end{array}$ & $\begin{array}{l}\text { Di-seupan } \\
\text { (steamed); } \\
\text { fried }\end{array}$ & $\begin{array}{l}\text { Di-seupan } \\
\text { (steamed); } \\
\text { fried }\end{array}$ & $\begin{array}{l}\text { Di-seupan } \\
\text { (steamed) }\end{array}$ \\
\hline
\end{tabular}

Table 1 informs that generally, people use suweg for jaburan/ jajabur (additional food). The community even emphasized that $i$ is not a staple food like rice. Jaburan suweg is generally eaten together, either within the scope of one's own family or with neighbors. The time to eat jaburan suweg is generally during the day which is sometimes supplemented with other snacks or drinks such as tea or coffee. The age group that still likes to eat suweg is generally the elderly, not young age groups such as children or adolescents. This is because there are many alternative foods available and also many young age groups who do not know the suweg itself. Some people inform that suweg is sometimes a choice or top priority for processing into food compared to other root crops such as taro, cassava, or sweet potato. This is related to scarcity, that is, apart from being a small population, it also only exists during certain seasons.

The public informs that the part or organ of the suweg that is a beuti (tuber). The way to process suweg tubers into food is by steaming (the local term is $d i$ seupan). The stages of making a steamed suweg are (i) beuti di-pesek (tuber skin removed); (ii) the tubers cut into small pieces (the local term is di-keureut-an) such as orange paste or about 2-4 ramo (fingers)/ $2-8 \mathrm{~cm}$ or depending on the taste or condition of the tubers, can also be shaped like cubes; (iii) the tubers are washed (the local term is di-kumbah) toroughly with cai (water) flowing or not flowing until teu leueur (not slippery) 
with the aim of removing dirt/ sap/ itching; (iv) the tubers are steamed (di-seupan) for about 15-30 minutes/ 30 minutes/ 20 minutes/ 1 hour using a panci/ aseupan (a pyramid-shaped container made of woven bamboo which functions to cook rice or cook food by steaming), it is better to cook it using a suluh (firewood) so that the taste is more savory, the water for steaming must be boiled (the local term is nga-golak) so that the tubers of suweg do not itch after cooking; (v) seupan suweg is served (without adding salt and grated coconut or can also be added with the two ingredients). Especially in Sindangpanji and Jagasari Villages, the term urab (seupan suweg given salt and grated coconut) is still popular in the community. Meanwhile, in Cipulus and Cilancang villages the term $u r a b$ is not or less popular.

Apart from being steamed (di-seupan), the community informed that the tubers of suweg were also processed into food by frying. Generally, this frying process is carried out if the suweg swallow is not eaten up. The method of frying the tubers of suweg is through stages (i) steaming (di-seupan); (ii) frying in cooking oil using a frying pan. There were also people who informed about frying the tubers of suweg with other variations, namely (i) the tubers to be steamed ( $d i$ seupan); (ii) di-tutu (pounded); (iii) di-emple-keun (dough is formed); (iv) the dough is cut; (v) the dough is fried. In addition, there were also people who informed about how to fry the tubers of suweg through the following stages: (i) peeled the skin of the tubers; (ii) the tubers are cut into small pieces; (iii) the tubers are washed; (iv) the tubers are fried; (v) fried tubers are served. Processing of suweg tubers by frying directly without going through di-seupan process like this is rarely done.
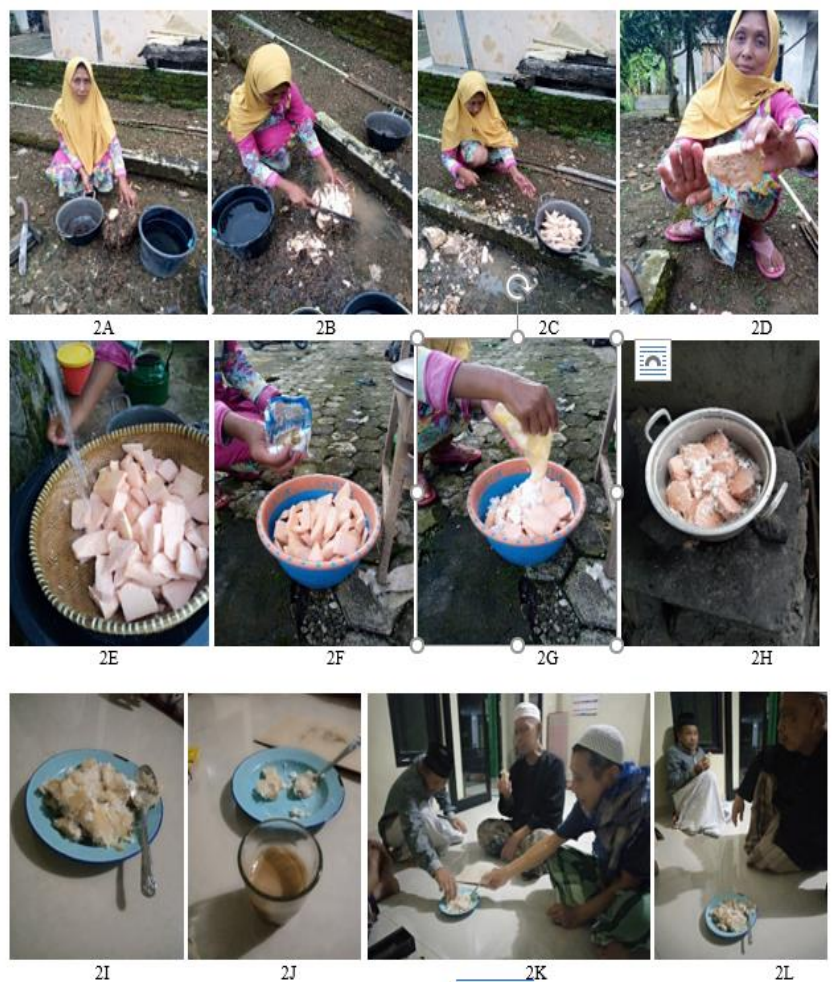

Figure 2. Seupan (steamed) of suweg: processing (2A-2H); dish (2I, 2L).
Especially in Sindangpanji Village, apart from jaburan, suweg is also used to feed fish such as gouramy (Osphronemus goramy) (Table 1). This is related to the large number of fish ponds in Sindangpanji Village compared to Cipulus Village and Cilancang Village, which have higher topographical positions and few water sources. The parts or organs of the suweg that are used for fish feed are the leaves and petioles that are generally still growing, not those that have withered. How to use it for fish feed is the strands and stalks of suweg leaves di-gebrus-keun (dropped) or di-alungkeun (thrown) into the fish pond (Figure 3).

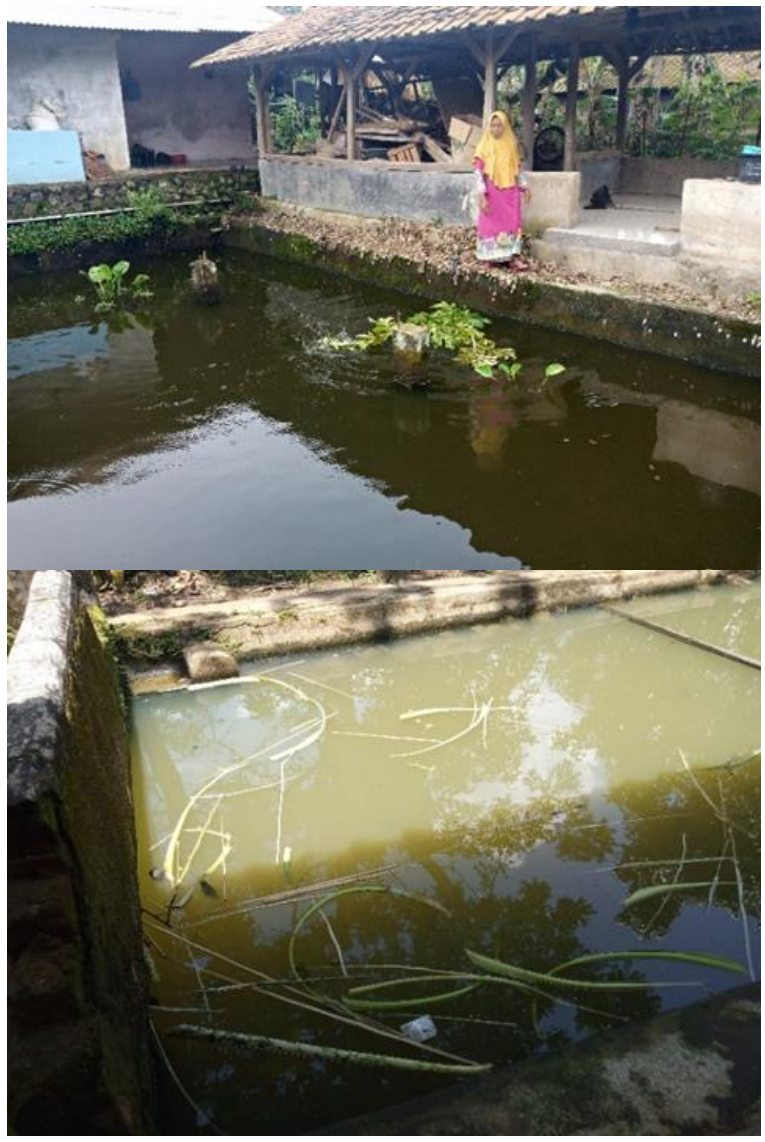

Figure 3. Suweg is used to fish feed in ponds

\subsection{Cultivation of Suweg}

Regarding cultivation of the suweg, the community has knowledge about methods, status, or others which can be seen in more clearly in Table 2 and the following description:

Table 2 Community knowledge in around the Ciremai Mount about cultivation of the suweg

\begin{tabular}{|c|c|c|c|c|}
\hline \multirow[t]{2}{*}{ Description } & \multicolumn{4}{|c|}{ Desa } \\
\hline & Cipulus & Cilancang & Jagasari & Sindangpanji \\
\hline Cultivation & $\begin{array}{l}\text { Not } \\
\text { cultivated } \\
\text { intensively }\end{array}$ & $\begin{array}{l}\text { Not } \\
\text { cultivated } \\
\text { intensively }\end{array}$ & $\begin{array}{l}\text { Not } \\
\text { cultivated } \\
\text { intensively }\end{array}$ & $\begin{array}{l}\text { Not } \\
\text { cultivated } \\
\text { intensively }\end{array}$ \\
\hline Commodity & $\begin{array}{l}\text { Not a } \\
\text { commodity }\end{array}$ & $\begin{array}{l}\text { Not a } \\
\text { commodity }\end{array}$ & $\begin{array}{l}\text { Not a } \\
\text { commodity }\end{array}$ & $\begin{array}{l}\text { Not a } \\
\text { commodity }\end{array}$ \\
\hline
\end{tabular}


In general, Table 2 informs that the suweg is not cultivated specifically or intensively like other cultivated plants, but it is not completely wild. If planted intentionally, the steps for planting a suweg are as follows: (i) the seeds are buried in the soil with a hoe or 2 hoes (about the size of 1 or 2 hoes) or about $20 \mathrm{~cm}$ in diameter with a depth of 15 or $20 \mathrm{~cm}$; (ii) allowed to grow on its own. There are also people who inform that seeds of the suweg are simply sown (in local term is $d i$ awur-keun) over their home gardens or gardens without being buried in a hole that was deliberately made. When planting is done at the beginning of the rainy season (usum ngijih).

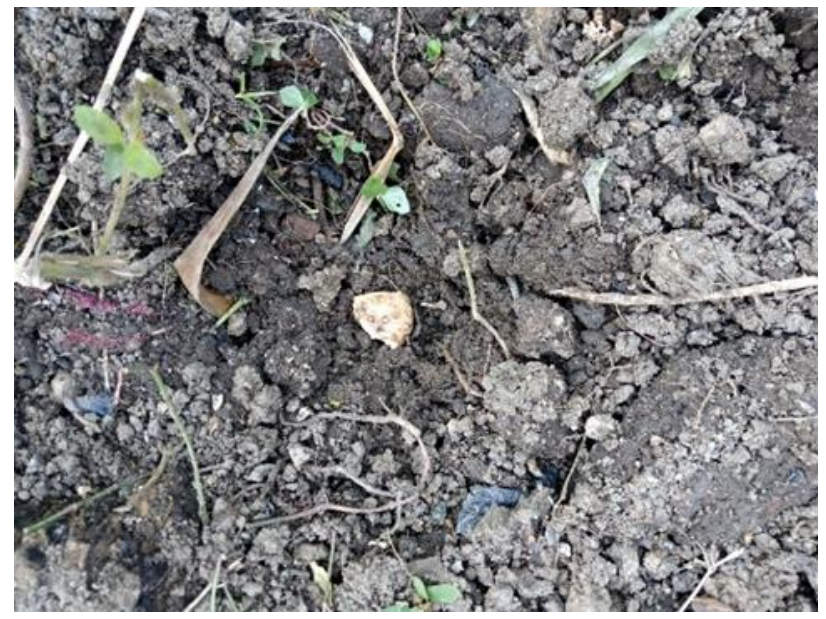

$3 \mathrm{~A}$

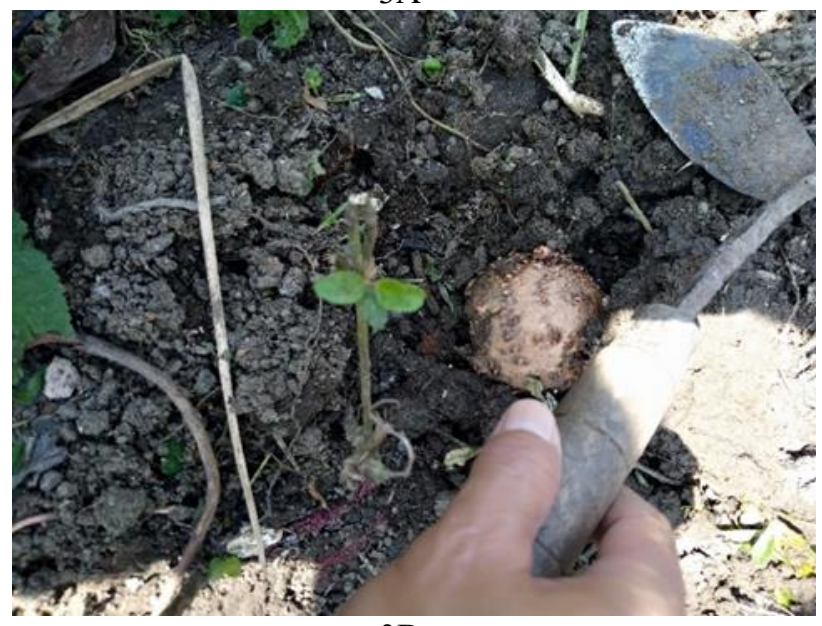

$3 \mathrm{~B}$

Figure 4. Suweg planting: seed from the peel of tuber skin $(3 \mathrm{~A})$ and seed from the small tuber (3B)

The community informed that seeds of the suweg generally come from peeled tuber skin (cangkang beuti) or shoots attached to tubers or small tubers (Figure 4). In addition, the seeds can also come from suweg saplings that grow in one place and then move them to another desired land. Furthermore, the community informed that there was no special treatment for the already planted suweg seeds such as fertilization and pest/ weed eradication. However, sometimes people do weeding (in local term is ngored) if there is grass or other species of plants that grow around the suweg. Some people say that the suweg does not have pests. The community believes that the suweg can grow and develop on its own (in local term is jadi sorangan) even without human treatment which can further encourage growth or development as in other species of cultivated plants.

Suweg tubers that are used by the community are harvested at the time of the dry season (usum halodo). Characteristic of the suweg that is right for harvest is when the leaves and stalks turn yellow or wither, fall (in local term is tumpur) which indicates that they are old (Figure 5). If the stalk of suweg is still in its infancy to harvest the tubers, then the tubers feel itchy, ganyah, cambewek, cangor/ nyakrek/ nyawek, are also small in size. The community further informed that if the suweg was not harvested during the harvest season, the tubers in the ground were sometimes reversed so that the concave part where the petiole grew below. The purpose of turning the tubers is so that in the following season the tubers develop into bigger ones. In addition, if the tubers have been harvested, they must be processed immediately to make snacks/ food (a maximum of about 2 days after harvest). If not processed immediately (about 1 week), the tubers will turn black and taste bad.

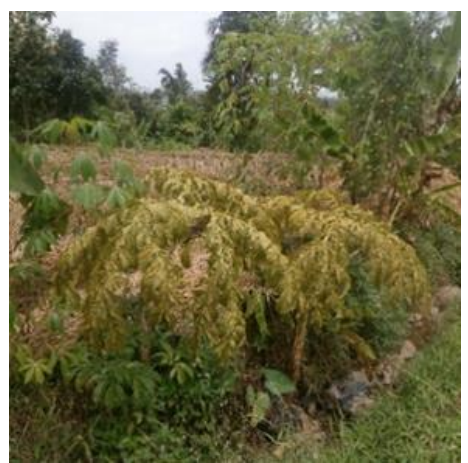

$4 \mathrm{~A}$

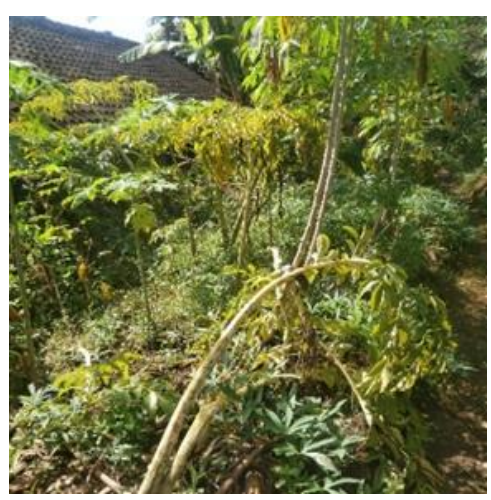

$4 \mathrm{~B}$

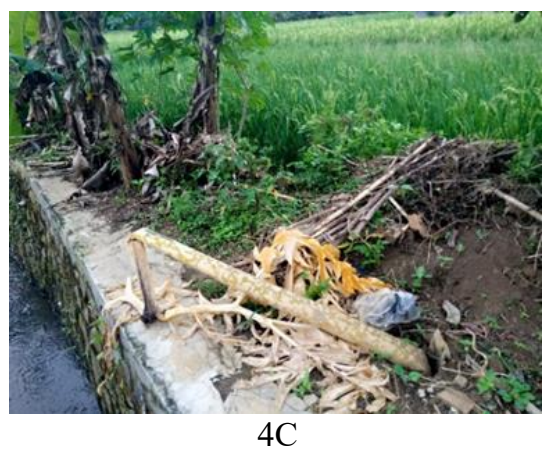

Figure 5. Suweg ready for harvest: leaves turn yellow (4A) or fall/ wilt $(4 \mathrm{~B}, 4 \mathrm{C})$ 
The community also informed that planting suweg (including provision of seeds, land preparation, planting, maintenance, and harvesting) does not require special costs and there are no taboo matters or is related to certain traditional ceremonies. Likewise, suweg is not traded or is not a cultivated commodity like other root crops such as cassava, sweet potato, or taro. This is because there are no traders who buy or market places to sell suweg. People use suweg for their own or social interests such as consumption (subsistence).

\section{Discussion}

Related to the finding of suweg in several existing land types, this is in line with what Mutaqin et al. (2020) that the behavior of the community by allowing the suweg to grow and planting seeds (even though they are not harvested or utilized later) is something that can support the conservation or sustainability of growth of the suweg, genetically. Likewise, the tilization of suweg for several purposes can support the survival of individuals or the population of suweg. Amusa et al. (2010) inform that efforts to conserve natural resources can be supported through the management and utilization of the resources concerned by the community. More in principle, conservation efforts for resources must pay attention to the economic, social, and cultural aspects of the community $[31,27,11]$. In addition, the transfer of local knowledge from generation to generation, including the utilization and cultivation of suweg, can maintain a type of resource to survive. The existence of erosion or loss of local knowledge possessed by a community has serious implications for various conservation efforts $[32,11]$.

Related to the reduced utilization of suweg by the community, several things are in line with several scientific literature. Erosion or stagnation in the transfer of local knowledge within a community, including the use of resource, is triggered by external factors or processes outside the community [33, 11]. Iskandar et al. (2018) stated that socio-economic changes have an impact on genetic diversity. Likewise, Prihatini et al. (2018) stated that the market economic system affects people's interest in cultivating crops on the land they own, which tends to plant species of plants that have commercial value and are more homogeneous or have low diversity.

Related to the use of suweg by the community, several things are in line with several scientific studies. Koni et al. (2017) stated that this plant can be used for food, although its use is limited because of the high content of oxalate and low crude protein it contains. Likewise, Kumar et al. (2015) states that this plant is consumed as a cooked vegetable. Likewise, Mubarok \& Santoso (2018) stated that Amorphophallus sp. is one of the most important crops, namely as food crops.

Specifically related to how to cook suweg, several things are in line with several scientific libraries. Mutaqin et al. (2020) inform that the tubers of suweg are eaten by the people of Cisoka Village, Majalengka Regency through processing by steaming (di-seupan). Meanwhile, Hasanah et al. (2014) informed that the people in Bantarkawung sub District, Brebes Regency, boiled, made compote, or made flour.

The use of suweg by the community for additional food may ethically be related to its habits and nutritional content. In general, Hanafie (2010) informed that most groups of root crops are used by the community for snacks, not for staple food. Ramalingam et al. (2010) informed that this Amorphophallus contains constituents of carbohydrates, proteins, alkaloids, tannins, glycosides, phenols, flavonoids, saponins, volatile oils, and starch. Meanwhile, Srivastava et al. (2014) informed that the constituents contained in this type of Amorphophallus consist of carbohydrates, protein, fat, crude fiber, iron, chromium, magnesium, nitrogen, phosphorus, copper, zinc, manganese, and potassium.

Regarding information from the public that suweg tubers must be cleaned before cooking to relieve itching or cook by heating (steaming), ethically this may be related to the substance in the tubers, namely calcium oxalate. In general, calcium oxalate compounds are found at all taxonomic levels, from small algae to higher gymnosperms. This compound is found in several plant organs such as leaves and roots [42]. Tooulakou et al. (2016) inform that calcium oxalate in land plants is often found in large enough quantities, up to $80 \%$ of dry biomass. One of the characteristics of calcium oxalate rafide is that it can cause itching in several parts of the human body such as the mouth, throat, and skin [44, 45, 46]. Furthermore, Rofi'ana et al. (2018) stated that washing with $\mathrm{NaCl}$ solution could affect the oxalate content in purple yam tubers, a plant that is a family of suweg, where the higher the concentration of $\mathrm{NaCl}$ in the solution, the more it affects the reduction in the oxalate content of the tubers. Lukitaningsih et al. (2012) informed that the washing process of suweg tubers can relieve itching due to the presence of calcium oxalate contained in the tubers. Singh et al. (2018) inform that treating the corms of Amorphophallus paeoniifolius (Dennst.) Nicolson by alum and salt and then cooking peat low oxalate content. In addition, Chandrasekara \& Kumar (2016) informed that processing can affect the bioactivity of constituent compounds. Tubers are generally processed by boiling, frying, baking and roasting, dehydration, and fermentation, depending on the region and country in different types of foods are prepared at domestic and industrial levels. Syamsiah (2011) concluded that the processing method affects the calcium oxalate content in tire tubers (Amorphophallus sp.), Both processed by boiling, soaking in salt water, or by melting wood ash. The processing method that is most effective in reducing or minimizing the calcium oxalate content is processing through boiling with an average calcium oxalate content of $0.008 \%$. The boiling process itself includes: (1) washing and stripping the tubers, (2) slicing the tubers, (3) boiling. Dewi et al. $(2017)^{[50]}$ inform that steaming with the addition of activated charcoal can reduce oxalate levels in taro tubers, a plant belonging to the araceae family which is related to suweg. Meanwhile, Widari \& Rasmito (2018) informed that the largest reduction percentage of $90.9 \%$ calcium oxalate was obtained in boiling for 25 minutes with a concentration of $\mathrm{NaCl}$ solution, $8 \%$. Amalia \& 
Yuliana (2013) informed that to reduce the calcium oxalate content, boiling time and the size of the Alocasia macrorrhiza tuber slices, plants that are a family of suweg, the optimum is 30 minutes and $1 \mathrm{~cm}$ respectively.

Related to information from the community, the group that consumes food in the form seupan is generally the elderly group, not the young age group. Adiasih \& Brahmana (2015) informs that the young age group (students) do not know information about traditional foods. Yuliati (2011) concluded that the factors that influence consumers in purchasing traditional food are personality factors (including age, gender, and education level), price, promotion, culture, knowledge, location or place, experience and lifestyle. In general, Qazzafi (2020) concluded that there are four main factors which affect consumer behavior such as personal factors (age and stages of life cycle, occupation, personality and lifestyle), psychological factors (motivation, perception, learning and memory), social. and economic factor (personal income, family income, income expectations, savings, consumer credit and other economic factors).

Related to information from the public that besides being used for food, suweg is also used for fish feed, this is in line with several other research results. Mutaqin et al. (2020) informs that the community in Cisoka Village, Majalengka Regency uses suweg in addition to additional food or traditional ceremonies, it is also used for fish feed, especially gouramy fish (Osphronemus goramy), tilapia fish (Oreochromis niloticus), nilem fish (Osteochilus vittatus), and gold fish (Cyprinus carpio). More broadly, Mutaqin et al. (2018) inform that the community uses several species of plants from the Araceae family, such as sente (Alocasia macrorrhizos) and taro (Colocasia esculenta) as fish feed.

Regarding the cultivation of suweg as informed by residents, several things are in line with several other scientific research results. Hidayah et al. (2013) states that activities in the cultivation of porang, plants of the same genus as suweg, generally include land preparation, seed preparation, planting, maintenance, and harvesting. More specifically, Narayan et al. (2018) informed several things related to cultivation of $A$. paeoniifolius. The things referred to include: seed size of $0.5 \mathrm{~kg}$ of whole corm or cut pieces at a row and plant spacing of $75 \mathrm{~cm}$ has been recommended for commercial cultivation while $100 \mathrm{~g}$ seed corm is required for seed production at a row and plant spacing of $50 \mathrm{~cm}$ each. Furthermore, pits of $30 \mathrm{~cm}$ each in length, width and depth are opened. Well rotten compost or vermicompost alongwith NPK inorganic form, neem or mustard cake are mixed with soil. After putting the seed corm in vertical position it is covered with soil upto $15 \mathrm{~cm}$ above ground level in pyramid shape to avoid rotting of corm in case of water logging.

Meanwhile, Mutaqin et al. (2020) informs several things related to the cultivation of suweg in Cisoka Village, Majalengka Regency, West Java Province. Traditionally, residents in the village usually grow seedlings from bud/ tubers and peeled tubers. The buds or peeled tubers are not treated specifically, for example, covered with ash, soaked, or given a fungicide. Suweg seedling sources that are intentionally planted can come from family or neighbors. Land preparation for suweg seedling that is intentionally planted in agroecosystem types, such as home gardens and gardens, follows land preparation for other staple crops. Suweg planting techniques generally are by burying buds or peeled tubers in a hole in the soil (up to a depth of about 10-15 $\mathrm{cm}$, with a hole width depending on the size of the seed) or left on the ground. Suweg that grow or are intentionally planted on cultivated land types are not specifically treated. There is no or lacked fertilization or pest / weed control specifically. If suweg grows on cultivated land, then the treatment of the staple crop will directly or indirectly affect the growth of the suweg. The treatments include controlling weeds, or in the local language commonly called ngored. In addition, tubers can be harvested if suweg is at least around 4 months or one planting season, during the dry season, and the stems have withered or fallen. If suweg tubers are harvested during the rainy season, the tubers are not tasty and watery or beueuy (in the local language). Another thing, if the tubers are harvested when the stems have not withered or are still in its infancy, then the tubers are itchy, small in size, not tasty and hard or cangor/ jagreug in local language. Likewise, if the tubers are not harvested in one season, then the tubers should be turned over so that they get bigger. Harvesting does not special preparations such as traditional ceremonies or certain forms of ritual.

Regarding information from the public that the suweg is harvested during the dry season, this is in line with several scientific research results. Nurlela et al. (2019) concluded that the highest glucomannan content of Amorphophallus muelleri, a plant of the same genus as suweg, was obtained in tubers taken at dormant. After growth reaches its maximum, glucomannan is no longer used for metabolic processes, but more accumulated in the tubers until the plant reaches the dormancy phase. As it is known that glucomannan is a polysaccharide consisting of glucose and mannose [60].

Regarding the statement of the population that in management, generally the suweg does not or rarely does control or control of possible disturbing pests, this is in line with what Mutaqin et al (2020) informed that the community in Cisoka Village, Majalengka Regency does not carry out special management of the suweg plant, including in terms of fertilization and pest/ weed control. But ethically, suweg actually has pests. Sreerag et al. (2014) inform that Amorphophallus paeoniifolius has a pest, namely the mealy bug (Rhizoecus amorphophalli) which can be controlled by a biofumigant.

\section{Conclusion}

Suweg is a resource that has its own important value. In areas around the Ciremai Mount which is included in the Cimanuk Watershed Region, this plant is used by residents mainly as additional food ingredients, which in the local language is popular with the term jaburan, which is subsistence or not a commodity. This plant has 
been growing in the area for a long time, but it is not cultivated intensively.

\section{Acknowledgment}

The authors would like to thank everyone, institutional, or stakeholders who have supported this research, especially Deputy for Strengthening Research and Development-Ministry of Research and Technology/ National Research and Innovation Agency, Rector of Padjadjaran University, the Head of village and many people in Cipulus Village, Cilancang Village, Jagasari Village, and Sindangpanji Village. This research was supported by Program Disertasi Doktor of Prof. Ir. Denny Kurniadie, M. Sc., with the main topic is titled as "Etnoecology of the suweg (Amorphophallus paeoniifolius (Dennst.) Nicolson) in wilayah perdesaan Cimanuk watersheds region" with the research implementation agreement number 1827/UN6.3.1/LT/2020

\section{References}

1. C. Kusmana \& A. Hikmat, The Biodiversity of flora in Indonesia, JPSAL 5, 2, 187-198 (2015)

2. Rugayah, K.S. Yulita, D. Arifiani, H. Rustiami, \& D. Girmansyah, Tumbuhan langka Indonesia: 50 jenis tumbuhan terancam punah (LIPI Press, Jakarta, 2017)

3. F. Ijaz, Z. Iqbal, I.U. Rahman, N. Ali, G. Qadir, M.A. Khan, A.U. Din, A.H. Shah, I. Ali, S. Hussain, A. Khan, M. Shah, and W. Sadiq, The role of plants in human welfare, JTMCN 6, 2, 1-4 (2017)

4. Z. Zhang and J. Zhou, From ecosystems to human welfare: the role and conservation of biodiversity, CR 49, 5, 1-17 (2019)

5. B. Schaal, Plants and people: Our shared history and future, PPP, 14-19 (2019)

6. W.G.D. Fernando, Plants: An International Scientific Open Access Journal to Publish All Facets of Plants, Their Functions and Interactions with the Environment and Other Living Organisms, Plants, 1, 1-5 (2012)

7. B.C. Bennett, Plants as Food. In Economic Botany. In Encyclopedia of Life Support Systems (EOLSS). Brad Bennett (Ed). Developed under the Auspices of the UNESCO (Eolss Publishers, Oxford, UK, 2010)

8. J. Yao, Y. Weng, A. Dickey, and K.Y. Wang, Review: Plants as factories for human pharmaceuticals: Applications and challenges, IJMS 16, 28549-28565 (2015)

9. A.M.A. Vasconcellos and M.V. Sobrinho, Knowledge and culture: two significant issues for local level development programme analysis. INTERAÇÕES, Campo Grande, 15, 2, 285-300 (2014)
10. C.M. Cotton, Ethnobotany: Principles and Applications (John Willey and Sons.Ltd, England, 1996)

11. J. Iskandar, Ethnobiology, Ethnoecology, and Sustainable Development (Plantaxia, Yogyakarta, 2018)

12. A.M. Carvalho and A.F. Moreira, Importance of local knowledge in plant resources management and conservation in two protected areas from Trás-os-Montes, Portugal, JEE 7, 36, 1-12 (2011)

13. D.M. Warren, L.J. Slikkerveer, and D. Brokensha (eds.), The cultural dimensions of development: Indigenous knowledge systems (Intermediate Technology Publication, London, 1995)

14. A. Maroyi and A. Cheikhyoussef, A comparative study of medicinal plants used in rural areas of Namibia and Zimbabwe, IJTK 14, 3, 401-406 (2015)

15. A.B. Suwardi, Indriaty, \& ZI Navia, Nutritional evaluation of some wild edible tuberous plants as an alternative foods, IJFS 6, 2, 9-12 (2018)

16. A. Chandrasekara and T.J. Kumar, Roots and tuber crops as functional foods: A review on phytochemical constituens and their potential health benefits, IJFS, 1-15 (2016)

17. K. Vaneker \& E. Slaats, Mapping edible aroids, Iridescent, 2, 3, 34-45 (2012)

18. R. Ramanathan, R. Bhuvaneswari, M. Indhu, G. Subramanian, and R. Dhandapani, Survey of ethnobotanical observation on wild tuberous medicinal plants of Kollihills, Namakkal district, Tamilnadu, JMPS 2, 4, 50-58 (2014)

19. J.E.M. Yabesh, S. Prabhu, and S. Vijayakumar, An ethnobotanical study of medicinal plants used by traditional healers in silent valley of Kerala, India, JE, 154, 774-789 (2014)

20. R. Mandal, S. Nag, J. Tarafdar, and S. Mitra, $A$ comparison of efficiency parameters of SSR markers genetic diversity analysis in Amorphophallus paeoniifolius (Dennst.) Nicolson, BABT, 59, 1-7 (2016)

21. A.Z. Mutaqin, D. Kurniadie, J. Iskandar, M. Nurzaman, and R. Partasasmita, Ethnobotany of suweg, Amorphophallus paeoniifolius: Utilization and cultivation in West Java, Indonesia, Biodiv. 21, 4, 1635-1644 (2020)

22. S.L. Tan \& A. Zaharah, Tuber crops: Tuber crops are underground crops. The most important ones in Malaysia are the white potato, the sweetpotato*, cassava and cocoyam, ASJ 1, 1, 41-48 (2015)

23. Yuzammi, A. Kurniawan, N.P.S. Asih, I. Erlinawati, and W. Hetterscheid, The Amorphophallus of Indonesia (Center for Plant Conservation Botanic Gardens, Indonesian Institute of Sciences, Bogor, 2017)

24. A.Z. Mutaqin, D. Kurniadie, J. Iskandar, M. Nurzaman, and R. Partasasmita, Ethnobotany of suweg (Amorphophallus paeoniifolius): Folk classification, habitat, and traditional 
conservation in Cisoka Village, Majalengka District, Cimanuk Watershed Region, Indonesia, Biodiv. 21, 2, 546-555 (2020)

25. Statistics of Majalengka Regency, Cikijing district innfigures (Statistics of Majalengka Regency, Majalengka, 2018)

26. J.W. Creswell, Research Design Qualitative, Quantitative, and Mixed Approaches (Pustaka Pelajar, Yogyakarta, 2014)

27. H. Newing, C.M. Eagle, R.K. Puri, and C.W. Watson, Conducting Research in Conservation: Social Science Methods and Practice (Routledge, London, 2011)

28. J. Iskandar \& B.S. Iskandar, Ethnobotanical study on food crop diversity in swidden agroforestry agriculture to support food security of Baduy community, in Proceedings of the National Seminar on the Society for Indonesian Biodiversity, SIB, 16 June 2015, Bandung (2015)

29. https://id.wikipedia.org/wiki/Daftar_kecamatan_da n_kelurahan_di_Jawa_Barat, (2020)

30. T.O. Amusa, S.O. Jimoh, P. Aridanzi, M. Haruna, Ethnobotany and conservation of plant resources of Kainji Lake National Park, Nigeria, Ethnobot Res Appl 8, 181-194 (2010)

31. A.B. Cunningham, Applied Ethnobotany: People, World Plant Use \& Conservation (Earthscan, London and Sterling, 2001)

32. M. Lizarralde, Indigenous knowledge and conservation of the rainforest: Ethnobotany of the Bari of Venezuela. In Carlson TJS and Maffi L (eds), Ethnobotany and conservation of biocultural diversity (New York Botanical Garden, New York, 2004)

33. N. Ross, Lacandon Maya Intergenerational Change and the Erosion of Folk Biological Knowledge. In Stepp et. al. (eds), Ethnobiology and Biocultural Diversity (The Intrnational Society of Ethnobiology, Athens, 2002)

34. J. Prihatini, J. Iskandar, R. Partasasmita, and D. Nurjaman, The impacts of traditional homegarden conversion into the commercial one: A case study in Sukapura Village of the upstream Citarum Watershed, West Java, Indonesia. Biodiversitas 19, 5, 1926-1940 (2018)

35. T.N.I. Koni, Zuprizal, Rusman, C Hanim, Nutrient evaluation of fermented Amorphophallus campanulatus as poultry feed, Int. J. Poult. Sci. 16, 12, 511-514 (2017)

36. P.R.K. Kumar, S.K. Kolli, J. Suneetha, and G. Hemanth, Cultivation of Amorphophallus paeoniifolius (Dennst) Nicolson (Elephant foot yam) in Kovvur Mandal of West Gidavari District, Andhrapradesh India, IJPR, 7, 5, 15549-15553 (2015)

37. A.S.F.Q.R. Mubarok and I. Santoso, Community response to Amorphophallus sp. agroindustrial empowerment using partial least square, Habitat 29, 3, 99-105 (2018)
38. U. Hasanah, E.P. Hadi, \& H.A. Hidayah, Diversity and uses of tuber as alternative food sources in Bantarkawung Brebes Regency, Biosfera 31, 2, 61-70 (2014)

39. R. Hanafie, The role of traditional staple foods in diversifying food consumption, J-SEP 4, 2, 1-7 (2010)

40. R Ramalingam, K.H. Bindu, B.B. Madhavi, A.R. Nath, and D. Banji, Phyto chemical and anthelmintic evaluation of corm of Amorphophallus campanulatus, IJPBS V1, 2, 1-9 (2010)

41. S. Srivastava, D. Verma, A. Srivastava, S.S. Tiwari, B. Dixit, R.S. Singh, and A.K.S. Rawat, Phytochemical and nutritional evaluation of Amorphophallus campanulatus (Roxb.) Blume, JNFS 4, 3, 1-6 (2014)

42. J. Ahmed, K. Ojha, S. Vaidya, J. Ganguli, and A.K. Ganguli, Formation of calcium oxalate nanoparticles in leaves: significant role of water content and age of leaves. Current Sci. 103, 3, 293-298 (2012)

43. G. Tooulakou, A. Giannopoulos, D. Nikolopoulos, P. Bresta, E. Dotsika, M. G. Orkoula, C. G. Kontoyannis, C. Fasseas, G. Liakopoulos, M. I. Klapa, and G. Karabourniotis, Alarm Photosynthesis: Calcium Oxalate Crystals as an Internal CO2 Source in Plants, Plant Phys. 171, 2577-2585 (2016)

44. J.H. Bradbury, R.W. Nixon, The acridity of raphides from edible aroids, JSFA 76, 608-616 (1998)

45. M.N. Lewu, P.O. Adebola, A.J. Afolayan, Effect of cooking on the mineral contents and antinutritional factors in seven accessions of Colocassia esculenta (L.) Schott growing in South Africa, JFCA 23, 389-393 (2010)

46. A.K. Singh, A.K. Chaurasiya, and S. Mitra, Oxalate content in elephant foot yam (Amorphophallus paeoniifolius Dennst-Nicolson) Dry and Fry cubes, JPP 7, 2, 2905-2909 (2018)

47. Rofi' ana, S.W.A. Suedy, and S. Parman, Effect of soaking of $\mathrm{NaCl}$ solution on reduction of calcium oxalate and size of amylum on purple yam (Dioscorea alata L.). NICHE J. Trop. Bio. 1, 1, 1-6 (2018)

48. E. Lukitaningsih, Rumiyati, \& I. Puspitasari, Study of glicemikc index and macronutrient content from tubers to find alternative functional food, Pharmacon, 13 1, 18-23 [Indonesian] (2012)

49. Syamsiah, The influence of processing method of tire tuber (Amorphophallus sp.) toward the level of calcium oxalate, Bionature 12, 2, 63-69 (2011)

50. S.K. Dewi, B. Dwiloka, \& B.E. Setiani, The reduction of oxalate level in taro tuber with the addition of active carbon using steaming method, JATP 6, 2, 1-4 (2017)

51. N.S. Widari \& A. Rasmito, Penurunan kadar kalsium oksalat pada umbi porang 
(Amorphophallus oncophyllus) dengan proses pemanasan di dalam larutan $\mathrm{NaCl}$, J. Tek. Kim. 13, 1, 1-4 (2016)

52. R. Amalia \& R. Yuliana, Study of the process of soaking and boiling the calcium oxalate content in senthe tubers (Alocasia macrorrhiza (L.) Schott), JTKI 2, 3, 17-23 (2013)

53. P. Adiasih \& R.K.M.R. Brahmana, Perceptions of traditional East Javanese food: A preliminary study of private university students in Surabaya, Kinerja 19, 2, 112-125 (2015)

54. C. Yuliati, Factors that influence consumers in purchasing traditional snack food in Malang City, JMB 1, 01, 7-20 (2011)

55. S. Qazzafi, Factor affecting consumer buying behavior: a conceptual study, IJSRD 8, 2, 1205 1208 (2020)

56. A.Z. Mutaqin, M. Fatharani, J. Iskandar, \& R. Partasasmita, Utilization of Araceae by local community in Cisoka Village, Cikijing subDistrict, Majalengka District, West Java, Indonesia, Biodiv. 19, 2, 560-571 (2018)

57. R.Hidayat, D.Dewanti,\& Hartojo, Porang plant: Characteristics, benefits, and cultivation (Graha Ilmu, Yogyakarta, 2013)

58. A. Narayan, R. Prasad, P.P. Singh, and R.S. Singh, Elephant foot yam (AMorphophallus paeoniifolius): money spinning tuber crop for doubling farmers income of Bihar, Int.J.Curr.Microbiol.App.Sci, 7, 1014-1021 (2018)

59. Nurlela, N. Ariesta, E. Santosa, and T. Muhandri, Effect of harvest timing and length of storage time on glucomannan content in porang tubers. IOP Conf. Series: Earth and Environmental Science, 299 (2019)

60. D.A. Bender. 2020. A dictionary of food and nutrition.

https://www.oxfordreference.com/view/10.1093/ac ref/9780199234875.001.0001/acref-

9780199234875-e-

2398 ? $r$ skey $=$ bjFauh \&result $=3155$ (accessed on 24 December 2020)

61. R.S. Sreerag, C.A. Jayaprakas, L. Ragesh, and K.S. Nishanth, Standarisation of biofumigant isolated from leaves of four major tuber crops against the mealy bug, Rhizoecus amorphophalli, JEZS 2, 4, 145-150 (2011) 